\title{
Corporate Disclosure in a Voluntary Reporting Environ- ment: NYSE-listed Firms in 1900
}

\author{
Michelle Namkoong ${ }^{1}$, Eric Hilt ${ }^{1}$ \\ ${ }^{1}$ Economics Department, Wellesley College, Wellesley, MA, USA \\ Corresponding author: mnamkoon@wellesley.edu \\ DOI: $10.47611 /$ jsr.v9i1.1061
}

\section{$\underline{\text { ABSTRACT }}$}

This paper examines the financial reporting done by firms listed on the New York Stock Exchange in 1900 and the firm characteristics that determined what and how much firms would disclose. At this time, there were no federal disclosure mandates or stringent requirements imposed by the Exchange. Therefore, the reporting done by firms was largely voluntary and resulted in significant variation across companies and industries. I look at all 191 firms that listed stocks on the NYSE in this year and use data from Moody's Manual of Industrial and Miscellaneous Securities and Poor's Manual of the Railroads of the United States to determine the amount of financial disclosure. I find that more capital-intensive firms were more likely to report income statements and balance sheets and provided more volume of information. In addition, food, mining, and miscellaneous service firms disclosed the least. In addition, all else equal, the age of a company and offering preferred stock did not significantly increase its likelihood of reporting financial statements. Overall, the results indicate that even absent regulation, firms would voluntarily provide information but at varying degrees based on how much the company relies on outside investors and whether its industry is competitive. They also suggest that managers considered potential or explicit investor demand for financial information and responded to this demand.

\section{Introduction}

Before the 1929 stock market crash, the government and exchanges like the New York Stock Exchange (NYSE) imposed few mandates on American firms on the level and quality of financial information they had to provide. In addition to being rarely enforced, mandates were easily avoidable by listing on different exchanges or trading as "unlisted" securities. Furthermore, there were no accounting standards or audit requirements, so the information actually reported was questionable in its accuracy. Firms did still disclose some information to investors, though. How did managers of these firms choose what kind of information and how much detail to disclose to the public? This paper examines what kinds of firm characteristics likely determined the financial information reported by firms listed on the NYSE in the year 1900. This sample and year are ideal in evaluating what factors influenced disclosure, because the environment meant more discretion than the early- or mid-twentieth century, especially after 1929. While regulatory agencies like the Securities and Exchange Commission (SEC) had not yet been established by 1900, there was simultaneously growing debate over the need for greater financial reporting in the age of trusts [1]. Therefore, at the turn of the century, there was significant variation in what corporations publicly reported on their financials, even on basic aspects such as a balance sheet or revenues [2]. This cross-sectional variation provides greater insight into any patterns of disclosure across firms and industries, as well as look at how managers responded 
to investor demand, if at all.Hawkins (1963) gives a detailed account of how modern financial reporting practices among American manufacturers came about from the nineteenth to the mid-twentieth century. Sivakumar and Waymire (1993) look at NYSE industrial corporations from 1905-1910 and the relationship between stock price behavior and annual earnings reports. Barton and Waymire (2004) find that the quality of firms' reporting increases with managers' incentives to supply financial information to investors, and that firms with higher quality financial reporting before October 1929 had lower stock price declines during the crash. There are numerous papers exploring positive accounting theory, which focuses on managers' motives for accounting choices when there are agency costs and information asymmetry, although they focus on con-temporary accounting standards and twentieth century firms [3]. Voluntary disclosure literature focuses on the role of financial reporting in capital markets; again though, these papers look at firms under modern regulatory conditions [4]. Leftwich, Watts, and Zimmerman (1981) do a similar study on voluntary corporate disclosure by looking at interim reporting, but they examine firms listed on the NYSE or American Stock Exchange in 1948. There is therefore little research on firms in the late nineteenth century in the area of corporate disclosure, particularly on the factors of why managers supplied certain information to investors.

I test several hypotheses where the dependent variable is a reporting measure, such as whether or not the firm has an income statement and the number of lines in the statement. My independent variables include firm age, location, capital stock (as a proxy for size), bonded debt, bonded debt amount, and preferred stock. I hypothesize that companies with bonded debt would be more likely to provide financial statements and with greater detail, due to a new class of claimants on the firm's assets. Larger-sized firms would also be likely to provide more financial information. Shareholder demand for information is likely higher for younger, and therefore newer, companies. Firms operating in states farther from the Northeast region (i.e. from the NYSE) would provide more detailed financial statements to remedy the issue of distance. Finally, industries with competition among firms, such as manufacturing and mining, would be biased towards financial secrecy because of antitrust and competition-related concerns.

Up until 1933, the federal government left U.S. corporations largely unregulated and required no financial disclosure from them. Railroads were an exception with regards to federal regulation, as the Interstate Commerce Commission (ICC) was formed in 1887 to ensure fair rates, eliminate rate discrimination, and prevent abuse of power among the dominant railroad companies. However, the ICC had little enforcement ability and did not have strict requirements on disclosure specifically, and Attorney General Richard S. Olney described the agency as one that "satisfies the popular clamor for a government supervision of the railroads, at the same time that such supervision is almost entirely nominal." [5]. The Sherman Antitrust Act of 1890 was still a fairly new piece of legislature, which made it less effective at preventing railroad monopolies and the prevailing corruption among management in the industry. Some states had begun to pass "blue sky" laws in the late nineteenth century in an effort to protect investors against fraudulent securities. These laws mandated annual reports from corporations, although they lacked specificities on what and how such information should be provided to the public. By 1900, only sixteen states required detailed reports, defined as requiring financial statements in detail of assets and liabilities of the company. Eleven states required a more basic, general statement on the condition of the company, which often only required the firm description and directors' names; the rest of the states required no report at all. Furthermore, most of these states did not penalize companies that failed to comply with these provision conditions, largely because they lacked the ability to enforce them. Companies could move to other states to avoid compliance, and companies operating across state borders were barely monitored at all.

However, at the turn of the century, Congress was also just starting to recognize the need for more regulation of the growing number of large businesses. In 1898, Congress established the Industrial Commission to "consider and recommend legislation to meet the problems presented by labor, agriculture, and capital." [6]. At the time, there was a general belief that more corporate publicity would help eradicate the growing "social, political, and economic evils brought about by the various trusts and combinations." [6]. In 1900, the Industrial Commission heard from various witnesses on the issue of trusts and mergers - many of them owners and board directors of industrial companies. Based on these testimonies, the Commission submitted to Congress a set of recommendations, which were the first proposals of a federal agency to pass laws to regulate industrial financial reporting standards. The 
Commission members, like others who championed more disclosure, were vague on what specific details should be disclosed to "ensure safe and intelligent investment" [7]. The Commission's recommendations did not take form as federal legislation until the 1933 Securities Acts.

Given the federal and state governments' lack of regulation, the NYSE attempted to at least impose more rules on its own listed firms. Since 1869, the NYSE recommended that firms publish annual reports on a company's finances to its shareholders. These reports referred to annual financial statements and notice of any significant corporate events. Companies were required to publish annual and interim reports to both the exchange and the firm's stockholders. Few companies followed this and it was only first enforced in 1897, when the NYSE demanded the Kansas City Gas company promise to comply with a minimum reporting requirement. The Exchange only extracted a written promise from the company, though, and did not threaten to remove the firm from its listings. Generally, any announced standards were barely imposed and companies that did not want to report could easily avoid doing so by going to other exchanges. Due to this issue of competing exchanges, the NYSE was especially disinclined to enforce its reporting rules on management of industrial firms. In an effort to prevent any firms leaving for the competition, in 1885 the NYSE created the Unlisted department. Companies that were "unlisted" were not required to provide financial information relevant to the issue, but their shares were still traded alongside regular listed securities and distinguished only with an asterisk. Most of the unlisted firms were industrial companies - 43 of the 68 NYSE unlisted preferred or common stocks and bonds were manufacturing firms' stocks [8]. Consequently, for many years, fairly large and active companies like Amalgamated Copper and American Sugar Refining provided no financial information whatsoever to the public. As a result, it was up to managers of companies to decide what was released to stockholders and the general public, and their decisions were likely influenced by various factors, such as firm characteristics, industry norms, and investor demand.

Since managers determined what and how much financial information would be disclosed to the public, their inclination towards less disclosure, or "financial secrecy" should be further broken down. These factors include the lack of precedent for disclosure, lack of public demand, lack of accounting standards, and the way in which securities were bought and sold.

Arguably the most important factor as to why managers were predisposed to financial secrecy was because there was no precedent for companies to reveal their operations to the public, or more importantly, to their competitors. Throughout the nineteenth century, most manufacturing firms were small, relatively local businesses. Owners were also typically in constant contact with the management, if they weren't the managers themselves. Furthermore, there were few, if any, outside investors. For most manufacturing companies, nearly all of the shares were owned by the original owner family so there was no need to communicate internal costs, profits, etc. to shareholders. As a result, a company's financial statement was considered to be strictly private information. It naturally followed that even as firms started becoming larger in the 1880's, managers did not believe the public had rights to a company's finances and operations. In 1899, when a member of the Industrial Commission questioned Henry O. Havemeyer, President of the American Sugar Refining Co., "You think then, that the public has no right to know what [a corporation's] earning power is or to subject them to any inspection whatever, that the people may not buy stock blindly?" Havemeyer replied: "Yes, that is my theory. Let the buyer beware; that covers the whole business." To be fair, at the time it appeared that the general public mirrored management's view on financial secrecy as appropriate and even necessary, as "few buyers and apparently fewer sellers were disturbed by the absence of financial statements." [7].

In addition, a structural aspect contributing to lack of disclosure was that accounting was a fairly new field. Accounting standards did not yet exist, which contributed to nondisclosure, inaccurate information, and varying ways and terms to report the same points in a statement across firms and industries. Finally, investors in the nineteenth century usually did not buy securities based on their own research and the financial state of the firm in question. Instead, investors based their purchases on their trust in the investment bank or promoter offering the issue, because of the prevalent notion that investment bankers researched the securities very well and only offered 
"investment quality" securities. These factors and reporting environment in the late nineteenth century help explain the range of disclosure in companies' financial statements found in the data collected for the year 1900.

After 1900, the rise of big business and simultaneous increase in investors drove the need for more disclosure and standardization of reporting across firms and industries. As companies became larger and publicly owned, managers and owners were no longer one and the same. In 1900 there were about 500,000 stockholders in the United States, which increased to nearly 10,000,000 by 1930 [7,9]. Many critics of big business believed the growing power imbalance between investors and managers to be a major problem, and this was confirmed by the numerous cases of fraud. Therefore, the doctrine of caveat emptor - that it is solely the buyer's responsibility to check the quality of his or her investment - was now void and corporate nondisclosure was no longer acceptable [10].

The Progressive era, a period from the late 1890's to World War I, was an influential movement, and progressives like Samuel Gompers argued that big business suppressed competition and therefore went against economic progress. Congress and the U.S. courts were not "insensitive to the demand for corporate reform," and the Industrial Commission, Bureau of Corporations, and Justice Department antitrust suits did involve major companies like Swift and Company and Standard Oil of New Jersey [6]. During Theodore Roosevelt's presidency, Congress' newly formed Bureau of Corporations especially utilized public corporate transactions to bring down the alleged "bad" trusts [6].

However, although there was increased regulation, there was not yet legislative transformation on corporation financial reporting requirements. The most substantial legislative change to address industrial corporate disclosure came with the 1933 Securities Acts. Railroads were distinct, because the existing ICC gained more power in regulating the industry by establishing a uniform accounting system in 1908 to ensure fair rates and non-discrimination [11]. This came about from widespread public upset over the railroad companies' continued abuse of their monopoly power and the corrupt behavior in the form of "watered stock, stock market rigging, dishonest management, rate wars, rebating, and labor violence" throughout the nineteenth century [5].

The NYSE was making more progress than the federal or state governments, possibly motivated by the increasing threat of government regulation [9]. In 1910, the exchange terminated its Unlisted department and from 1910-1930, the NYSE's Committee on Stock List took on a larger role in improving the disclosure practices of listed firms.

The Great Depression in 1930 altered the entire general public's view of business in the United States, and the subsequent election of Franklin D. Roosevelt in 1932 and the Securities Acts of 1933 most fully transformed the financial reporting environment. The Securities and Exchange Commission was the primary mechanism through which the federal government enforced more comprehensive and reliable disclosure from firms after 1933. After the crisis, policymakers believed investor losses would have been lessened had firms been more transparent, particularly in their financial statements. The SEC was there-fore meant to protect investors from abuse by informed traders as well as big businesses [12]. The American Institute of Accountants, the reorganization of the American Association of Public Accountants, also worked with the SEC to continuously improve accounting standards from the 1930's to the 60's [9].

\section{Data and Methodology}

The data sources used include the Commercial and Financial Chronicle (CFC), Moody's Manual of Industrial and Miscellaneous Securities, and Poor's Manual of the Railroads of the United States. The CFC was published every Saturday and was widely perceived as a more complete source of corporate financial information than daily newspapers like The New York Times and The Wall Street Journal [13]. Moody's was an annual publication that included "practically all official information available concerning all the more important companies." [13]. Moody's data are used in similar early twentieth century corporate disclosure research [2]. Similarly, Poor's was an annual report first published in 1968 and had since "play[ed] a major role in the development of the provision of reliable information" to both managers and investors alike [14]. 
The 191 firms examined were all listed on the New York Stock Exchange as indicated in the "Stocks" section for the December 1900 issue of the CFC. The majority of non-railroad firms provided financial statements, operations descriptions, management information, or a combination in Moody's 1900 annual report. Eighteen firms (19 percent) of the non-railroad firms did not provide information in the 1900 report, but ten of these did provide information in the 1901 report on 1900 operations, so these were recorded instead. Since Moody's was first published in 1900, the firms may have not known about publishing in Moody's or were delayed in reporting. Therefore, since only ten firms did not report in 1900 but did in 1901, I thought it acceptable to use these reports for these instances. Only one of 95 railroads were not listed in Poor's Manual.

I collected data based on the firm's respective reporting in either Moody's or Poor's for the most recent year, which included indicators for whether a firm had any form of an income statement or balance sheet and the number of lines for each statement. The lines for each statement did not include any final balance lines. Other variables collected included age of the firm, which was calculated as the year of the firm's corporation subtracted from 1900. The state(s) of operation and incorporation were also collected, and the region indicators reflect the state(s) of operation. The region groups of West, Midwest, Northeast, and South were based on the U.S. census regional map. Other indicators included whether the firm had preferred stock, disclosed its capital stock, and had bonded debt. Capital stock and bonded debt amount were also recorded, and the logged values were taken for the regressions. If given, the stock outstanding value for the firm was used; otherwise, the total capital stock amount was taken. Additional disclosure aspects were also recorded, which included values of revenues, operating expenses, taxes, property, and depreciation reserves, if reported.

A typical entry in 1900 for a non-railroad firm includes a description of the company's business, its bonded debt if applicable, capital stock, and the names of its officers. Some firms also included some kind of income statement, balance sheet, or both, although these greatly varied in length and detail from firm to firm. The railroad industry was more transparent than industrials and provided incredibly detailed financial statements in Poor's. Each railroad entry in Poor's would span several pages, and there were more established reporting norms in the industry, such as providing the past eight years of operations costs and earnings. Historical research suggests that railroads reported such detailed financial statements as a response to running such large, capital-intensive corporations that depended on outside financing and because the railroads were also subject to regulation by the ICC and taxing by state governments [15].

Based on Moody's classification scheme, I categorized firms by industry: food, manufacturing, mining, miscellaneous (e.g. service firms), railroads, and utilities. Table 1 provides descriptive statistics for all firms and by industry. All variables relating to income statements or balance sheets are conditional on whether or not the firm provides any kind of income statement or balance sheet. Other variables, like state of operation, preferred stock dummy, and the bonded debt variables, were not conditional on income statement or balance sheet, since this information was available and usually provided by firms regardless of whether they disclosed any further financial detail.

Table 1. Descriptive statistics of NYSE-listed firms in 1900

\begin{tabular}{|lccccccc|}
\hline & All Firms & Food & Manufacturing & Mining & Misc. & Railroads & Utilities \\
\hline Age & 17.2 & 4.78 & 6.88 & 12.4 & 10.8 & 22.5 & 19.1 \\
& $(-18.63)$ & $(-5.585)$ & $(-9.568)$ & $(-12.21)$ & $(-9.96)$ & $(-20.62)$ & $(-20.12)$ \\
Location & & & & & & & \\
West & 0.131 & 0.222 & 0.077 & 0.526 & 0.091 & 0.106 & 0 \\
& $(-0.338)$ & $(-0.441)$ & $(-0.272)$ & $(-0.513)$ & $(-0.302)$ & $(-0.31)$ & $(0)$ \\
Midwest & 0.461 & 0.889 & 0.538 & 0.158 & 0.182 & 0.521 & 0.522 \\
& $(-0.5)$ & $(-0.333)$ & $(-0.508)$ & $(-0.375)$ & $(-0.405)$ & $(-0.502)$ & $(-0.511)$ \\
Northeast & 0.366 & 0.556 & 0.846 & 0.158 & 0.455 & 0.277 & 0.391 \\
& $(-0.483)$ & $(-0.527)$ & $(-0.368)$ & $(-0.375)$ & $(-0.522)$ & $(-0.45)$ & $(-0.499)$ \\
South & 0.225 & 0.222 & 0.346 & 0.211 & 0.364 & 0.223 & 0.13 \\
& $(-0.419)$ & $(-0.441)$ & $(-0.485)$ & $(-0.419)$ & $(-0.505)$ & $(-0.419)$ & $(-0.344)$
\end{tabular}




\begin{tabular}{|c|c|c|c|c|c|c|c|}
\hline \multicolumn{8}{|l|}{ Capital Stock } \\
\hline $\begin{array}{l}\text { Preferred } \\
\text { stock dummy }\end{array}$ & $\begin{array}{c}0.524 \\
(-0.501)\end{array}$ & $\begin{array}{c}0.889 \\
(-0.333)\end{array}$ & $\begin{array}{c}0.846 \\
(-0.368)\end{array}$ & $\begin{array}{c}0.368 \\
(-0.496)\end{array}$ & $\begin{array}{c}0.455 \\
(-0.522)\end{array}$ & $\begin{array}{c}0.564 \\
(-0.499)\end{array}$ & $\begin{array}{c}0.217 \\
(-0.422)\end{array}$ \\
\hline Capital stock & & & & & & & \\
\hline dummy & $\begin{array}{c}0.937 \\
(-0.243)\end{array}$ & $\begin{array}{c}1 \\
(0)\end{array}$ & $\begin{array}{c}0.923 \\
(-0.272)\end{array}$ & $\begin{array}{c}0.947 \\
(-0.229)\end{array}$ & $\begin{array}{c}1 \\
(0)\end{array}$ & $\begin{array}{c}1 \\
(0)\end{array}$ & $\begin{array}{c}1 \\
(0)\end{array}$ \\
\hline $\begin{array}{l}\text { Log(capital } \\
\text { stock) }\end{array}$ & $\begin{array}{c}16.5 \\
(-1.888)\end{array}$ & $\begin{array}{c}17 \\
(-0.763)\end{array}$ & $\begin{array}{c}17.2 \\
(-1.03)\end{array}$ & $\begin{array}{c}15.9 \\
(-1.296)\end{array}$ & $\begin{array}{c}16.2 \\
(-1.211)\end{array}$ & $\begin{array}{c}16.6 \\
(-2.348)\end{array}$ & $\begin{array}{c}16.1 \\
(-1.084)\end{array}$ \\
\hline $\begin{array}{l}\text { Bonded debt } \\
\text { dummy }\end{array}$ & $\begin{array}{c}0.707 \\
(-0.456)\end{array}$ & $\begin{array}{l}0.667 \\
(-0.5)\end{array}$ & $\begin{array}{c}0.462 \\
(-0.508)\end{array}$ & $\begin{array}{c}0.368 \\
(-0.496)\end{array}$ & $\begin{array}{c}0.182 \\
(-0.405)\end{array}$ & $\begin{array}{c}0.957 \\
(0.203)\end{array}$ & $\begin{array}{c}0.783 \\
(-0.422)\end{array}$ \\
\hline $\begin{array}{l}\text { Log(bonded } \\
\text { debt amount) }\end{array}$ & $\begin{array}{c}16.1 \\
(-1.697)\end{array}$ & $\begin{array}{c}14.9 \\
(-0.86)\end{array}$ & $\begin{array}{c}14.7 \\
(-1.754)\end{array}$ & $\begin{array}{c}14 \\
(-1.67)\end{array}$ & $\begin{array}{c}13.2 \\
(-1.818)\end{array}$ & $\begin{array}{c}16.6 \\
(-1.541)\end{array}$ & $\begin{array}{c}15.7 \\
(-1.114)\end{array}$ \\
\hline Disclosure & & & & & & & \\
\hline $\begin{array}{l}\text { Income State- } \\
\text { ment dummy }\end{array}$ & $\begin{array}{c}0.696 \\
(-0.461)\end{array}$ & $\begin{array}{c}0.556 \\
(-0.527)\end{array}$ & $\begin{array}{c}0.692 \\
(-0.471)\end{array}$ & $\begin{array}{c}0.263 \\
(-0.452)\end{array}$ & $\begin{array}{c}0.364 \\
(-0.505)\end{array}$ & $\begin{array}{c}0.915 \\
(-0.281)\end{array}$ & $\begin{array}{c}0.652 \\
(-0.487)\end{array}$ \\
\hline $\begin{array}{l}\text { Income state- } \\
\text { ment lines }\end{array}$ & $\begin{array}{c}12.4 \\
(-6.866)\end{array}$ & $\begin{array}{c}4.6 \\
(-2.881)\end{array}$ & $\begin{array}{c}7.28 \\
(-5.05)\end{array}$ & $\begin{array}{c}4.6 \\
(-3.507)\end{array}$ & $\begin{array}{c}4.25 \\
(-3.202)\end{array}$ & $\begin{array}{c}15.8 \\
(-5.502)\end{array}$ & $\begin{array}{c}7 \\
(-4.957)\end{array}$ \\
\hline $\begin{array}{l}\text { Balance sheet } \\
\text { dummy }\end{array}$ & $\begin{array}{c}0.654 \\
(-0.477)\end{array}$ & $\begin{array}{c}0.444 \\
(-0.527)\end{array}$ & $\begin{array}{c}0.692 \\
(-0.471)\end{array}$ & $\begin{array}{c}0.053 \\
(-0.229)\end{array}$ & $\begin{array}{c}0.273 \\
(-0.467)\end{array}$ & $\begin{array}{c}0.957 \\
(-0.203)\end{array}$ & $\begin{array}{c}0.391 \\
(-0.499)\end{array}$ \\
\hline $\begin{array}{l}\text { Balance sheet } \\
\text { lines }\end{array}$ & $\begin{array}{c}17.9 \\
(-9.452)\end{array}$ & $\begin{array}{c}12.3 \\
(-4.726)\end{array}$ & $\begin{array}{c}16.2 \\
(-4.926)\end{array}$ & $\begin{array}{c}8 \\
(0)\end{array}$ & $\begin{array}{c}15.3 \\
(-0.577)\end{array}$ & $\begin{array}{c}19.1 \\
(-10.43)\end{array}$ & $\begin{array}{c}12.4 \\
(.4 .927)\end{array}$ \\
\hline $\mathrm{N}$ & 191 & 9 & 26 & 19 & 11 & 94 & 23 \\
\hline
\end{tabular}

The initial sample consists of 191 firms listed on the NYSE in 1900. Of this sample, only 182 firms provided information in Moody's or Poor's. Standard deviations are in parentheses.

Looking at Table 1, railroads are the oldest, on average, of the firms, which also provides an explanation for the industry's established norm of reporting more information than other industries. The majority of firms operate in the Midwest (46 percent) and the Northeast (37 percent). Roughly half of the firms over preferred stock, and nearly all of the firms provide their capital stock amounts. About 71 percent of firms have bonded debt. The two industries most likely to have bonded debt are railroads and utilities, which are capital-intensive. For disclosure, mining firms are the least likely to provide an income statement and balance sheet. This could be explained by the mining corporations being the most secretive, potentially for antitrust concerns, as regulators could have used the financial statements as evidence in antitrust suits.

I examine a set of related hypotheses. The first is that companies with bonded debt would be more likely to provide financial statements and with greater detail, because having bonded debt means an additional class of claimants on the firm. Conflicts could arise, contractual or otherwise, between these different claimants on the firm's assets, which may have been addressed by supplying more financial information [12]. The second hypothesis is that larger firms, in terms of capital stock, would provide more financial information because they were more dependent on outside investors, particularly less sophisticated investors that relied more heavily on financial statements to make investment decisions. I also predict that managers of younger firms would have recognized the additional risk in investing in their companies and mitigated this by providing more financial information. This was likely most significant for younger firms in new industries, like utilities, that were associated with technology and innovation. 
The fourth hypothesis is that firms operating in states farther from the Northeast region (i.e. from the NYSE) would provide more detailed financial statements to remedy the fact that investors would be less likely to be in regular contact with firm management or physically go to these firms to examine operations. Finally, I predict that industries with competition among firms, such as manufacturing and mining, would be biased towards financial secrecy. These firms would be concerned about revealing their information to competitors, but they would also have been more aware of the potential for antitrust issues since regulators could have utilized financial statements to make regulation decisions.

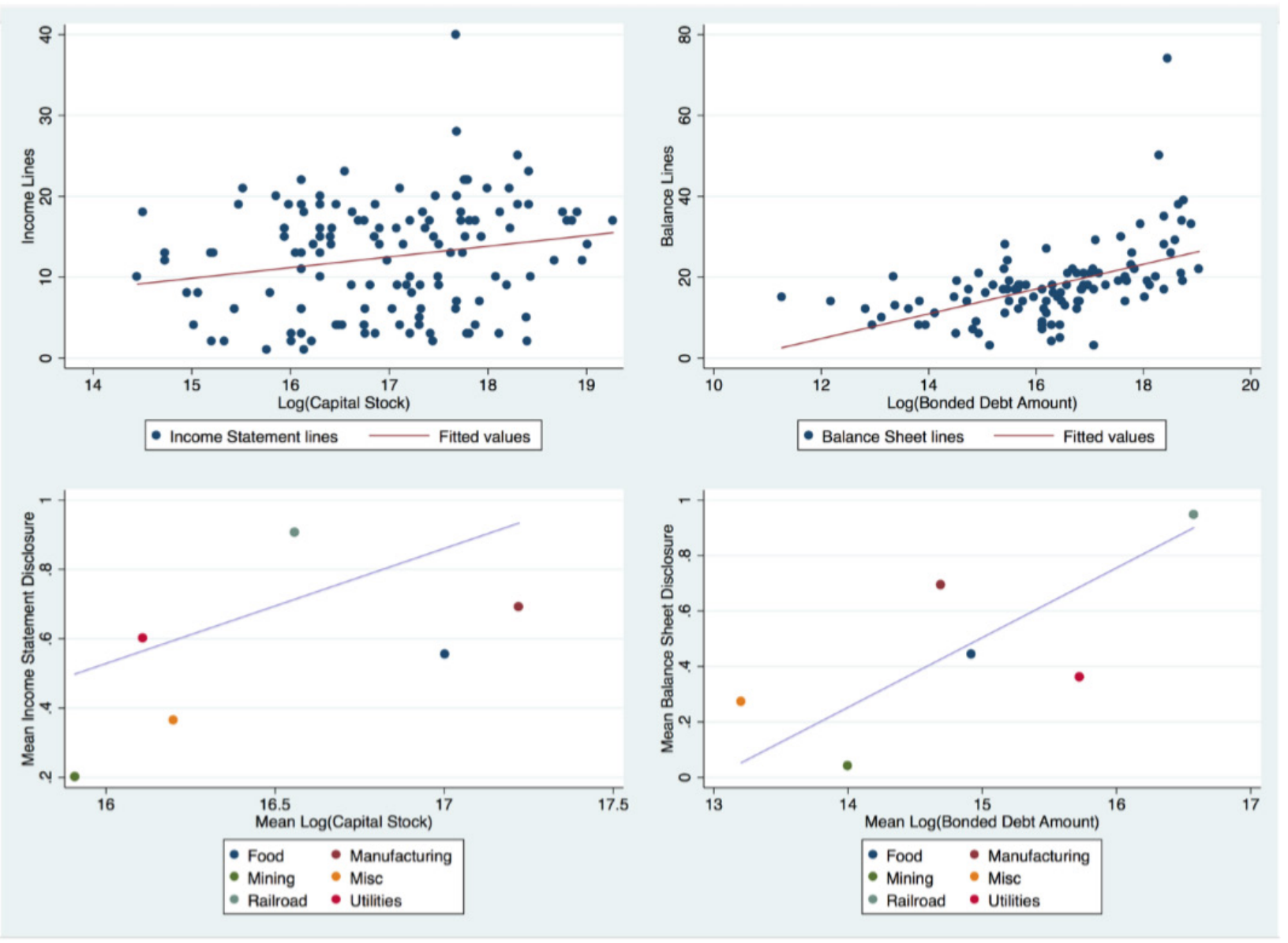

Figure 1. Disclosure and debt or capital

In Figure 1, the top two graphs show the number of income statement lines and balance sheet lines for all firms that disclosed relevant information. The bottom two show the means of the variables, grouped by industry for all firms that disclosed the relevant information.

As an initial test, I looked at a few of the independent variables' relationship with the dependent variables. The first two graphs in Figure 1 show a clear positive correlation between the log of capital stock amount and the number of income statement lines a firm has and the same positive trend between the log of bonded debt amount and balance sheet lines. In other words, the more capital stock or bonded debt a firm had, the more likely they were to disclose more information.

This was also the case for income statement and balance sheet disclosure across industries, as depicted in the second set of graphs in Figure 1. The graphs show the mean financial statement disclosure versus the mean $\log$ bonded debt amount or capital stock, grouped by industry. Based on these scatterplot results, there is fairly good 
evidence that certain firm characteristics determined whether, and how much, firms disclosed in an unregulated environment.

\section{Results}

The relationship between disclosure and firm characteristics is assessed for NYSE-listed firms using the regression below:

$$
\text { Disclosure }_{i}=\alpha+\beta_{1} \text { Age }_{i}+\beta_{2} \text { Industry }_{i}+\beta_{3} \text { Region }_{i}+\beta_{4} \text { Log }_{(\text {capital stock })_{i}}+\epsilon
$$

The equation includes age, industry dummies, region dummies, and $\log$ (capital stock). Table 3 reports the ordinary least-squares (OLS) estimation results. The excluded industry group is Railroads and the excluded region is the Northeast. The coefficient on age was negative for almost all of the variables but typically was very close to zero in all cases. This suggests that at least in 1900, the age of the firm was not an important firm characteristic in determining whether and how much managers disclosed. All of the industry indicator coefficients were statistically significant for nearly all of the dependent variables, and their negative sign makes sense given that railroads is the excluded group.

Table 3. Regression results

\begin{tabular}{|c|c|c|c|c|c|c|c|c|c|c|c|c|c|}
\hline \multirow{3}{*}{$\begin{array}{l}\text { Independent variable } \\
\text { Age }\end{array}$} & \multirow{3}{*}{$\begin{array}{l}\text { Predicted sign } \\
-\end{array}$} & \multicolumn{12}{|c|}{ Dependent variable } \\
\hline & & \multicolumn{3}{|c|}{ Income Statement } & \multicolumn{3}{|c|}{ Income Statement lines } & \multicolumn{3}{|c|}{ Balance Sheet } & \multicolumn{3}{|c|}{ Balance Sheet lines } \\
\hline & & $\begin{array}{l}-0.002 \\
(0.002)\end{array}$ & $\begin{array}{l}-0.002 \\
(0.002)\end{array}$ & $\begin{array}{l}-0.002 \\
(0.002)\end{array}$ & $\begin{array}{l}-0.004 \\
(0.027)\end{array}$ & $\begin{array}{l}-0.004 \\
(0.027)\end{array}$ & $\begin{array}{l}-0.009 \\
(0.030)\end{array}$ & $\begin{array}{l}0.000 \\
(0.002)\end{array}$ & $\begin{array}{l}-0.000 \\
(0.002)\end{array}$ & $\begin{array}{l}0.001 \\
(0.002)\end{array}$ & $\begin{array}{l}-0.021 \\
(0.049)\end{array}$ & $\begin{array}{l}-0.021 \\
(0.050)\end{array}$ & $\begin{array}{l}0.001 \\
(0.053)\end{array}$ \\
\hline \multicolumn{14}{|l|}{ Industry } \\
\hline Food & + & $\begin{array}{l}-0.453^{* * *} \\
(0.130)\end{array}$ & $\begin{array}{l}-0.439^{* *} \\
(0.132)\end{array}$ & $\begin{array}{l}-0.456^{* * *} \\
(0.132)\end{array}$ & $\begin{array}{l}-11.699^{* * *} \\
(2.392)\end{array}$ & $\begin{array}{l}-11.186^{* * *} \\
(2.454)\end{array}$ & $\begin{array}{l}-11.176^{* * *} \\
(2.463)\end{array}$ & $\begin{array}{l}-0.575^{* * *} \\
(0.118)\end{array}$ & $\begin{array}{l}-0.530^{* * * *} \\
(0.117)\end{array}$ & $\begin{array}{l}-0.545^{* * *} \\
(0.117)\end{array}$ & $\begin{array}{l}-9.072 \\
(5.459)\end{array}$ & $\begin{array}{l}-9.100 \\
(5.530)\end{array}$ & $\begin{array}{l}-9.568 \\
(5.537)\end{array}$ \\
\hline Manufacturing & + & $\begin{array}{l}-0.280^{* *} \\
(0.088)\end{array}$ & $\begin{array}{l}-0.255^{* *} \\
(0.096)\end{array}$ & $\begin{array}{l}-0.279^{* *} \\
(0.097)\end{array}$ & $\begin{array}{l}-9.243^{* * *} \\
(1.414)\end{array}$ & $\begin{array}{l}-8.336^{* * *} \\
(1.711)\end{array}$ & $\begin{array}{l}-8.252^{* * *} \\
(1.731)\end{array}$ & $\begin{array}{l}-0.274^{* * *} \\
(0.079)\end{array}$ & $\begin{array}{l}-0.194^{*} \\
(0.085)\end{array}$ & $\begin{array}{l}-0.214^{*} \\
(0.086)\end{array}$ & $\begin{array}{l}-4.861 \\
(2.551)\end{array}$ & $\begin{array}{l}-4.911 \\
(2.850)\end{array}$ & $\begin{array}{l}-5.261 \\
(2.862)\end{array}$ \\
\hline Mining & + & $\begin{array}{l}-0.601^{* * * *} \\
(0.116)\end{array}$ & $\begin{array}{l}-0.574^{* * * *} \\
(0.123)\end{array}$ & $\begin{array}{l}-0.549 * * * \\
(0.124)\end{array}$ & $\begin{array}{l}-12.306^{* * * *} \\
(2.669)\end{array}$ & $\begin{array}{l}-12.398^{* * *} \\
(2.672)\end{array}$ & $\begin{array}{l}-12.467^{* * * *} \\
(2.688)\end{array}$ & $\begin{array}{l}-0.824^{* * * *} \\
(0.105)\end{array}$ & $\begin{array}{l}-0.738^{* * * *} \\
(0.109)\end{array}$ & $\begin{array}{l}-0.717^{* * *} \\
(0.110)\end{array}$ & $\begin{array}{l}-14.893 \\
(9.489)\end{array}$ & $\begin{array}{l}-14.890 \\
(9.533)\end{array}$ & $\begin{array}{l}-15.208 \\
(9.522)\end{array}$ \\
\hline Miscellaneous & + & $\begin{array}{l}-0.611^{* * * *} \\
(0.131)\end{array}$ & $\begin{array}{l}-0.570^{* * * *} \\
(0.145)\end{array}$ & $\begin{array}{l}-0.583^{* * *} \\
(0.145)\end{array}$ & $\begin{array}{l}-13.583^{* * *} \\
(3.052)\end{array}$ & $\begin{array}{l}-11.991^{* * *} \\
(3.489)\end{array}$ & $\begin{array}{l}-11.976^{* * *} \\
(3.502)\end{array}$ & $\begin{array}{l}-0.706^{* * * *} \\
(0.118)\end{array}$ & $\begin{array}{l}-0.577^{* * *} \\
(0.129)\end{array}$ & $\begin{array}{l}-0.588^{* * *} \\
(0.129)\end{array}$ & $\begin{array}{l}-4.633 \\
(6.582)\end{array}$ & $\begin{array}{l}-4.678 \\
(6.710)\end{array}$ & $\begin{array}{l}-5.312 \\
(6.722)\end{array}$ \\
\hline Utilities & + & $\begin{array}{l}-0.220^{*} \\
(0.094)\end{array}$ & $\begin{array}{l}-0.217^{*} \\
(0.094)\end{array}$ & $\begin{array}{l}-0.188 \\
(0.096)\end{array}$ & $\begin{array}{l}-9.342^{* * * *} \\
(1.542)\end{array}$ & $\begin{array}{l}-9.441^{* * *} \\
(1.546)\end{array}$ & $\begin{array}{l}-9.554^{* * * *} \\
(1.580)\end{array}$ & $\begin{array}{l}-0.447^{* * * *} \\
(0.085)\end{array}$ & $\begin{array}{l}-0.435^{* * * *} \\
(0.084)\end{array}$ & $\begin{array}{l}-0.410^{* * *} \\
(0.085)\end{array}$ & $\begin{array}{l}-6.443^{*} \\
(3.190)\end{array}$ & $\begin{array}{l}-6.436^{*} \\
(3.210)\end{array}$ & $\begin{array}{l}-5.831 \\
(3.247)\end{array}$ \\
\hline \multicolumn{14}{|l|}{ Location } \\
\hline West & + & $\begin{array}{l}-0.087 \\
(0.095)\end{array}$ & $\begin{array}{l}-0.084 \\
(0.095)\end{array}$ & $\begin{array}{l}-0.098 \\
(0.095)\end{array}$ & $\begin{array}{l}-0.710 \\
(1.561)\end{array}$ & $\begin{array}{l}-0.645 \\
(1.563)\end{array}$ & $\begin{array}{l}-0.615 \\
(1.571)\end{array}$ & $\begin{array}{l}0.008 \\
(0.085)\end{array}$ & $\begin{array}{l}0.015 \\
(0.084)\end{array}$ & $\begin{array}{l}0.003 \\
(0.084)\end{array}$ & $\begin{array}{l}2.425 \\
(2.870)\end{array}$ & $\begin{array}{l}2.436 \\
(2.897)\end{array}$ & $\begin{array}{l}2.451 \\
(2.892)\end{array}$ \\
\hline Midwest & + & $\begin{array}{l}0.080 \\
(0.062)\end{array}$ & $\begin{array}{l}0.084 \\
(0.062)\end{array}$ & $\begin{array}{l}0.070 \\
(0.063)\end{array}$ & $\begin{array}{l}1.084 \\
(0.988)\end{array}$ & $\begin{array}{l}1.298 \\
(1.015)\end{array}$ & $\begin{array}{l}1.336 \\
(1.023)\end{array}$ & $\begin{array}{l}0.140^{*} \\
(0.056)\end{array}$ & $\begin{array}{l}0.153^{* *} \\
(0.055)\end{array}$ & $\begin{array}{l}0.141^{*} \\
(0.056)\end{array}$ & $\begin{array}{l}-1.321 \\
(1.900)\end{array}$ & $\begin{array}{l}-1.332 \\
(1.929)\end{array}$ & $\begin{array}{l}-1.591 \\
(1.939)\end{array}$ \\
\hline South & + & $\begin{array}{l}0.025 \\
(0.067)\end{array}$ & $\begin{array}{l}0.030 \\
(0.068)\end{array}$ & $\begin{array}{l}0.037 \\
(0.067)\end{array}$ & $\begin{array}{l}0.575 \\
(1.088)\end{array}$ & $\begin{array}{l}0.605 \\
(1.089)\end{array}$ & $\begin{array}{l}0.574 \\
(1.096)\end{array}$ & $\begin{array}{l}0.111 \\
(0.061)\end{array}$ & $\begin{array}{l}0.126^{*} \\
(0.060)\end{array}$ & $\begin{array}{l}0.132^{*} \\
(0.060)\end{array}$ & $\begin{array}{l}0.770 \\
(1.943)\end{array}$ & $\begin{array}{l}0.767 \\
(1.954)\end{array}$ & $\begin{array}{l}0.934 \\
(1.956)\end{array}$ \\
\hline \multicolumn{14}{|l|}{ Capital Stock } \\
\hline Log(capital stock) & + & $\begin{array}{l}0.032^{*} \\
(0.015)\end{array}$ & $\begin{array}{l}0.032^{*} \\
(0.015)\end{array}$ & $\begin{array}{l}0.028 \\
(0.015)\end{array}$ & $\begin{array}{l}0.597^{*} \\
(0.230)\end{array}$ & $\begin{array}{l}0.600^{*} \\
(0.231)\end{array}$ & $\begin{array}{l}0.614^{* * *} \\
(0.234)\end{array}$ & $\begin{array}{l}0.030^{*} \\
(0.014)\end{array}$ & $\begin{array}{l}0.030^{*} \\
(0.014)\end{array}$ & $\begin{array}{l}0.027 \\
(0.014)\end{array}$ & $\begin{array}{l}1.438^{* * * *} \\
(0.423)\end{array}$ & $\begin{array}{l}1.438 * * \\
(0.426)\end{array}$ & $\begin{array}{l}1.368^{* * *} \\
(0.429)\end{array}$ \\
\hline Bonded debt dummy & + & & $\begin{array}{l}0.055 \\
(0.084)\end{array}$ & $\begin{array}{l}0.036 \\
(0.084)\end{array}$ & & $\begin{array}{l}1.626 \\
(1.723)\end{array}$ & $\begin{array}{l}1.662 \\
(1.732)\end{array}$ & & $\begin{array}{l}0.174^{*} \\
(0.074)\end{array}$ & $\begin{array}{l}0.158^{*} \\
(0.075)\end{array}$ & & $\begin{array}{l}-0.120 \\
(3.024)\end{array}$ & $\begin{array}{l}-0.189 \\
(3.019)\end{array}$ \\
\hline Preferred stock dummy & + & & & $\begin{array}{l}0.104 \\
(0.067)\end{array}$ & & & $\begin{array}{l}-0.412 \\
(1.088)\end{array}$ & & & $\begin{array}{l}0.090 \\
(0.059)\end{array}$ & & & $\begin{array}{l}2.348 \\
(2.031)\end{array}$ \\
\hline Constant & & $\begin{array}{l}0.420 \\
(0.251)\end{array}$ & $\begin{array}{l}0.365 \\
(0.265)\end{array}$ & $\begin{array}{l}0.372 \\
(0.264)\end{array}$ & $\begin{array}{l}5.418 \\
(3.807)\end{array}$ & $\begin{array}{l}3.686 \\
(4.228)\end{array}$ & $\begin{array}{l}3.728 \\
(4.245)\end{array}$ & $\begin{array}{l}0.358 \\
(0.227)\end{array}$ & $\begin{array}{l}0.183 \\
(0.235)\end{array}$ & $\begin{array}{l}0.189 \\
(0.235)\end{array}$ & $\begin{array}{l}-3.822 \\
(7.171)\end{array}$ & $\begin{array}{l}-3.693 \\
(7.900)\end{array}$ & $\begin{array}{l}-4.190 \\
(7.900)\end{array}$ \\
\hline $\mathrm{N}$ & & 166 & 166 & 166 & 127 & 127 & 127 & 166 & 166 & 166 & 119 & 119 & 119 \\
\hline R-squared & & 0.324 & 0.326 & 0.337 & 0.505 & 0.509 & 0.509 & 0.507 & 0.524 & 0.531 & 0.177 & 0.177 & 0.188 \\
\hline
\end{tabular}

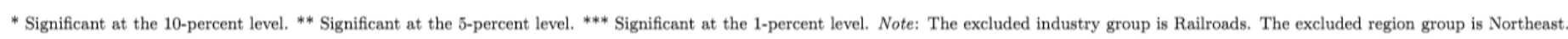

However, the coefficients are not significant for the number of balance sheet lines, aside from utilities. Since the number of balance sheet lines is conditional on having a balance sheet, this could be interpreted as firms disclosing much of the same amount of information in balance sheets if they do decide to disclose one publicly. 
$\log$ (capital stock) is significant in nearly all of the regressions, which is consistent with the hypothesis that larger firms would disclose more information. However, this is not the case for the bonded debt dummy, which may indicate that just having bonded debt does not necessarily make a firm more or less likely to disclose information. The preferred stock coefficient is also positive, but not significant, although this still indicates that firms with preferred stock did disclose, on average, more often than those without. The location variables are not consistently in the same direction, nor are they always in the same direction as predicted, aside from the regressions on balance sheet disclosure. This generally suggests that region of operation does not have much impact on disclosure outcome for firms, which may in turn imply that firms operating farther from the Northeast did not necessarily compensate for their distance by reporting more.

The firms expected to disclose the least relative to railroads are mining and miscellaneous (service firm) companies across all dependent variables. Food companies also disclosed little relative to rail-roads, although there were only 9 Food firms. My hypothesis was that industries with competition, such as manufacturing and mining, would be biased towards financial secrecy because of antitrust and competition-related concerns. The regression results show this is a plausible explanation for mining companies and miscellaneous companies. This was not the case for manufacturing; manufacturing and utilities companies were actually more similar in their coefficients across the regressions and relatively less negative than the other industries. It could be that this hypothesis is true and that miscellaneous and mining companies had more competition-related concerns than other firms, thus leading to their being the most financially secretive. An alternative explanation could be that manufacturing and utilities firms focused more on drawing in unsophisticated investors. Unsophisticated investors would have been the target audience for public financial information through Moody's and Poor's, so manufacturing and utilities firms may have actually provided more information to get these investors to buy their stocks. This is reasonable, but it is worthwhile to note that the mean $\log$ (capital stock) amounts were fairly different at 17.2 for manufacturing and 16.1 for utilities (see Table 1).

An interesting result to note is how the coefficient of $\log$ (capital stock) is statistically significant at the 1 and 5 percent level for the regressions on balance sheet lines. An interpretation of this could be that larger firms have more investors that would demand more detailed information on a firm's assets and liabilities.

In summation, the results shown in Tables 3 suggest that firms' disclosure levels of unregulated financial reports published in 1900 generally increases in firm characteristics that would increase investor demand for information, such as the industry of the firm, capital stock as a proxy for size, and the existence and amount of bonded debt. I conclude that managers responded to this demand by supplying this information in the form of income statements and balance sheets, even in a discretionary reporting environment.

\section{Discussion}

Looking at NYSE-listed firms in 1900, I provide evidence that managers do respond to existing or anticipated investor demand for disclosure even without regulatory requirements. I measure financial reporting as a firm's disclosure or nondisclosure of an income statement, balance sheet, and the number of income statement lines and balance sheet lines. The empirical analysis shows that these disclosure measures are significantly associated with variables that capture cross-sectional variation in firm characteristics and reporting demand, including firm industry, size, and bonded debt. The results suggest that firm characteristics that would prompt investor demand for financial reporting did result in managers disclosing statements, as well as more volume of information. These findings are consistent with the theory that managers would disclose more information if investors would demand more financial reporting for firms exhibiting certain characteristics. However, this level of information was likely not optimal, because critics and committees like the Industrial Commission called for more disclosure than the prevailing standards. This could be interpreted as managers of firms supplying financial information, even absent mandates, but that the optimal level of reporting would not be reached without requirements. 
The findings relate to issues of regulation, because they present evidence of voluntary disclosure without federal mandate. The results of this study indicate that certain firm characteristics are likely to lead managers to reveal more or less financial information. The results also show that firms disclosing information can be interpreted as a response to investor demand, since we would predict managers had little incentive to reveal financial information otherwise. Given the increased regulation after the crash in 1929 until present day, it is difficult to find an exact counterfactual environment to predict what kinds of firms would disclose financial information absent regulation. Therefore, the discretionary environment in 1900 presents a close real-world example of what firms would actually report voluntarily. We conclude that larger firms with more bonded debt in more capital-intensive industries would reveal more information in a setting without reporting requirements.

Other research shows the benefits to investors of firm financial transparency through investor protection, both under mandatory and voluntary disclosure environments. A number of such studies measured the benefits of such requirements by investor losses after a financial crisis. An additional research topic could be the presence of manager resistance to slight increases in regulation and the effect of these incremental mandates on a firm's stock prices. Further research could also build on existing studies to determine what the optimal level of financial reporting would be, if the goal is to protect investors while preserving the system of competition.

\section{Acknowledgments}

I would like to thank Professor Eric Hilt for his guidance and support on this research and for helping me achieve one of my most important goals.

\section{References}

[1] Brief, R. P. (1987). Corporate financial reporting at the turn of the century. Journal of Accountancy, 163(5), 142.

[2] Benston, G. J. (1973). Required Disclosure and the Stock Market: An Evaluation of the Securities Exchange Act of 1934. The American Economic Review, 63(1), 132-155.

[3] Watts, R. L., \& Zimmerman, J. L. (1978). Towards a Positive Theory of the Determination of Accounting Standards. Graduate School of Management, University of Rochester.

[4] Healy, P. M., \& Palepu, K. G. (1992). The Effect of Firms' Financial Disclosure Strategies on Stock Prices. Division of Research, Graduate School of Business Administration, Harvard University.

[5] Stover, J. F. (2008). American Railroads. University of Chicago Press.

[6] Hawkins, D. F. (1986). Corporate financial disclosure, 1900-1933: a study of management inertia within a rapidly changing environment. Facsimiles-Garl.

[7] Commission, I., \& Others. (1900). Preliminary Report of the Industrial Commission on Trusts and Industrial Combinations. Washington: Government Printing Office.

[8] Pratt, S. S. (1912). The Work of Wall Street: An Account of the Functions, Methods and History of the New York Money and Stock Markets. D. Appleton and Company.

[9] Hawkins, D. F. (1963). The Development of Modern Financial Reporting Practices among American Manufacturing Corporations. In Business History Review (Vol. 37, Issue 3, pp. 135-168).

https://doi.org/10.2307/3112231 
[10] Brandeis, L. D. (2009). Other People's Money and How the Bankers Use It. Cosimo, Inc.

[11] Sakolski, A. M. (1913). American Railroad Economics: A Text-book for Investors and Students. Macmillan.

[12] Barton, J., \& Waymire, G. (2004). Investor protection under unregulated financial reporting. Journal of Accounting and Economics, 38, 65-116.

[13] Fund, T. C. (1935). The Security Markets: Findings and Recommendations of a Special Staff of the Twentieth Century Fund; Directory of Survey; Alfred L. Bernheim; Staff Contributors; NR Danielian, G. Wright Hoffman, Paul D. Dickens [and Others]... Editors: Alfred L. Bernheim [and] Margaret Grant Schneider. Twentieth century fund, Incorporated.

[14] Chandler, A. D. (1981). Henry Varnum Poor, Business Editor, Analyst, and Reformer. Arno Press.

[15] Boockholdt, J. L. (1978). Influence of nineteenth and early twentieth century railroad accounting on the development of modern accounting theory. The Accounting Historians Journal, 5(1), 9-28.

[16] Sivakumar, K. N., \& Waymire, G. (1993). The Information Content of Earnings in a Discretionary Reporting Environment: Evidence from NYSE Industrials, 1905-10. Journal of Accounting Research, 31(1), 62-91.

[17] Leftwich, R. W., Watts, R. L., \& Zimmerman, J. L. (1981). Voluntary Corporate Disclosure: The Case of Interim Reporting. Journal of Accounting Research, 19, 50-77. 